\title{
WYKORZYSTANIE AKTYWNYCH METOD NAUCZANIA W SZKOLENIU SPECJALISTÓW DO SPRAV BEZPIECZEŃSTWA
}

\author{
Datsko O. S., Paraniak N. M.
}

\section{WPROWADZENIE}

Bezpieczeństwo jest jedną $\mathrm{z}$ podstawowych potrzeb człowieka $\mathrm{i}$ najważniejszą wartością. Problem ochrony ludzi przed zagrożeniami był istotny od czasu pojawienia się ludzkości na Ziemi. Każdemu zależy na bezpieczeństwie własnym i bliskich, tak jak ludzkość dba o bezpieczeństwo swojego istnienia. Wszyscy jesteśmy świadkami tego, że ostatnio świat zmienił się nie do poznania i nadal się zmienia. Szybki rozwój technologiczny współczesnego świata, oprócz pozytywnych zmian, prowadzi do nowych zagrożeń i niebezpieczeństw, które mogą mieć poważne konsekwencje dla ludzi i środowiska. Ludzkość nie może uniknąć wypadków spowodowanych przez człowieka, klęsk żywiołowych, sytuacji ekstremalnych, w wyniku których umierają ludzie, niszczone są wartości materialne i kulturowe, a gospodarka ponosi znaczne straty. Rok 2020 był punktem zwrotnym dla ponownego przemyślenia zrównoważonych paradygmatów rozwoju człowieka. Rozprzestrzenianie się COVID-19 i ograniczeń kwarantanny na całym świecie wymaga nowego podejścia do tworzenia bezpiecznych warunków życia i pracy. Wszystkie te zmiany wymagają pomysłowości, elastyczności, kreatywnego podejścia do rozwiązywania problemów, umiejętności zastosowania wiedzy $\mathrm{w}$ prawdziwym życiu. Jednak te umiejętności nie biorą się znikąd, trzeba je formować i rozwijać, także te związane ze szkoleniem specjalistów ds. Bezpieczeństwa.

Szkolenie specjalistów z zakresu bezpieczeństwa cywilnego na Ukrainie i w Unii Europejskiej ${ }^{1}$ ma na celu przeszkolenie inżynierów, którzy są w stanie zorganizować zarządzanie ochroną pracy i współpracę $z$ państwowymi organami nadzoru zgodnie $\mathrm{z}$ międzynarodowymi normami i standardami. Do ich kompetencji należy identyfikacja i ocena ryzyk zawodowych, zapewnienie realizacji działań profilaktycznych i innych, mających na celu eliminację szkodliwych i niebezpiecznych czynników produkcji, zapobieganie wypadkom przy pracy, chorobom zawodowym powodowanym przez warunki pracy.

1 Korzeniowski L., Wałek T. Edukacja dla bezpieczeństwa na polskich uniwersytetach. Securitologia, 2017, No 2, P. 1-17. 
Dziś, w okresie aktywnego wzrostu osiągnięć technicznych i zwiększającej się liczby wypadków i katastrof o charakterze antropogenicznym i środowiskowym, kraj potrzebuje również wysoko wykwalifikowanych specjalistów w dziedzinie bezpieczeństwa antropogenicznego i środowiskowego do monitorowania przestrzegania państwowych norm, norm i zasad bezpieczeństwa, zgodność $\mathrm{z}$ obowiązującymi przepisami, ustawodawstwo w zakresie ochrony ludności podczas projektowania, budowy, przebudowy, technicznego przezbrajania i eksploatacji budynków, budowli i innych obiektów, niezależnie od własności i działalności; kontrolowanie rozwoju i produkcji przyjaznych dla środowiska produktów, substancji i materiałów; eliminacja przyczyn i warunków, które przyczyniają się do powstawania i rozprzestrzeniania się zagrożeń spowodowanych przez człowieka i środowiska; opracowanie środków zapobiegających sytuacjom kryzysowym spowodowanym przez człowieka i naturę.

Skuteczne rozwiązanie problemów bezpieczeństwa personelu produkcyjnego, ludności i środowiska przez odpowiednich specjalistów stworzy bezpieczne i komfortowe środowisko życia dla ludzi. Takie podejście jest priorytetem we wszystkich krajach rozwiniętych.

\section{Przegląd aktywnych metod nauczania i ich zastosowania $\mathrm{w}$ kształceniu specjalistów $\mathrm{z}$ różnych dziedzin}

Zmiany społeczno-gospodarcze i rozwój informacyjny całej społeczności światowej wymagają rewizji istniejącego tradycyjnego systemu edukacji na ukraińskich uczelniach. Tendencja ta przejawia się w postaci sprzeczności między potrzebą ludzkiego rozwoju nowych dziedzin wiedzy a trudnościami ich pełnego rozwoju.

W tym zakresie problematyka rozwoju szkolnictwa wyższego w aspekcie integracji ze światową przestrzenią edukacyjną, rozwój twórczego myślenia, wprowadzanie postępów naukowych zgodnie z ich potrzebami, stwarzanie możliwości przekształcenia studenta w podmiot własnych działań . Przecież tylko specjalista z dobrym wykształceniem będzie mógł stać się aktywnym uczestnikiem gospodarczego, społecznego i kulturalnego rozwoju społeczeństwa.

Aktualne zagadnienia ukraińskiej polityki edukacyjnej to doskonalenie kształcenia specjalistów, radykalna aktualizacja naukowego i metodologicznego systemu kształcenia, doskonalenie form i metod kształcenia, zmniejszanie dystansu między faktycznym poziomem kształcenia a wymaganiami pracodawców, zapewnienie ciągłości kształcenia i analiza zagranicznych doświadczeń edukacyjnych.

Dlatego złożonym i ważnym zagadnieniem pedagogiki uczelni wyższych jest optymalizacja procesu szkolenia przyszłych specjalistów, rozwój kwalifikacji zawodowych, stworzenie nowego systemu poradnictwa 
zawodowego, kształcenie kompetentnych specjalistów. Szkolenie takiej kadry wymaga zintensyfikowania procesu dydaktycznego, wypracowania nowych form i metod nauczania.

Ukształtowanie osobowości aktywnej społecznie wymaga stosowania niestandardowych form interakcji pedagogicznej. Aby usprawnić i zintensyfikować proces edukacyjny w szkolnictwie wyższym, ważne jest uwzględnienie cech szkolnictwa wyższego, które wymuszają restrukturyzację stereotypów pracy pedagogicznej studentów i wyposażenie ich w nowe umiejętności i zdolności do działań edukacyjnych i poznawczych ${ }^{2}$.

Technologia aktywnego uczenia się polega na stosowaniu takich metod nauczania, które koncentrują się na osobowości ucznia, jego aktywnym udziale w samorozwoju, zdobywaniu wysokiej jakości wiedzy, umiejętności zawodowych, twórczych rozwiązaniach konkretnych problemów ${ }^{3}$.

Aktywne metody nauczania mają na celu:

- rozwój myślenia studentów;

- zaangażowanie studentów w rozwiązywanie problemów jak najbliżej rzeczywistych sytuacji produkcyjnych;

- poszerzanie i pogłębianie wiedzy zawodowej,

- rozwój praktycznych umiejętności i zdolności;

- promowanie aktywizacji procesu edukacyjnego,

- zachęcanie studentów do twórczego udziału w nim;

- zapewnienie rozwoju i samorozwoju osobowości ucznia w oparciu o identyfikację jego indywidualnych cech i możliwości;

- promowanie rozwoju zdolności do refleksji, która pomaga uczniom w znalezieniu indywidualnego stylu aktywności zawodowej, pozwala osiągnąć odpowiednią samoocenę zawodową i osobistą, przewidywać i analizować wyniki swoich działań oraz podnosi poziom samoorganizacji.

Jedną z takich form aktywnego uczenia się jest zabawa jako sposób na rozwijanie twórczego potencjału przyszłego specjalisty.

Metody gry są skuteczne i charakteryzują się obecnością modeli gry przedmiotu, procesu lub czynności; aktywizacja myślenia i zachowania studenta; wysoki stopień zaangażowania $\mathrm{w}$ proces edukacyjny; obowiązkowa interakcja studentów między sobą a nauczycielem; emocjonalność i twórczy charakter lekcji; samodzielność uczniów w podejmowaniu decyzji; chęć zdobycia umiejętności i zdolności w stosunkowo krótkim czasie.

${ }^{2}$ Гурч Л. М. Впровадження інноваційних педагогічних технологій: вимоги сучасності. Проблеми і перспективи розвитку фінансової системи Украӥни. 2003. Вип. 9. С. 151-153.

3 Дяченко-Богун М. Активні методи навчання у вищому навчальному закладі. Витоки педагогічної майстерності. 2014. Вип. 14. С. 74-79. 
Głównym celem gier edukacyjnych jest kształtowanie u przyszłych profesjonalistów umiejętności łączenia wiedzy teoretycznej z praktycznymi zajęciami. Student będzie mógł opanować niezbędne umiejętności i zdolności zawodowe tylko wtedy, gdy wykaże się nimi dostatecznie zainteresowaniem i podejmie określone starania, tj. Samodzielnie połączy wiedzę teoretyczną zdobytą na wykładach, seminariach, z rozwiązywaniem konkretnych problemów produkcyjnych i wyjaśnianiem sytuacji produkcyjnych.

Aktywność w grach spełnia następujące funkcje: motywacyjną (interesujące dla uczniów); towarzyską (opanowanie elementów kultury komunikacyjnej przyszłych profesjonalistów); samorealizacyjną (każdy uczestnik gry odkrywa swoje możliwości); rozwojową (rozwój uwagi, woli i innych cech umysłowych); rozrywkową (dobra zabawa); diagnostyczną (wykrywanie odchyleń w wiedzy, umiejętnościach, zachowaniu); korekcyjną (wprowadzający pozytywne zmiany w strukturze osobowości przyszłych specjalistów).

Technologie aktywnego uczenia się są najbardziej zróżnicowane i pozwalają poszerzyć możliwości uczenia się i poprawić jakość nauczania.

Przyszli prawnicy, nauczyciele i pracownicy socjalni muszą poprawić swoje umiejętności dialogu, ponieważ ich zadaniem jest aktywna komunikacja $\mathrm{z}$ innymi ludźmi - uczestnikami procesu, studentami, wychowankami i emerytami. Debata to gra zaprojektowana, aby pomóc uczniom rozwinąć umiejętności potrzebne do poszerzenia wiedzy uczniów. Uczniowie uczą się logicznego i krytycznego myślenia, dostrzegania sprzeczności w pozornie najdoskonalszych wypowiedziach, przekonującego udowadniania swoich myśli i poglądów innym lub szerokiemu gronu odbiorców. W debacie ważniejszy jest proces uczenia się niż końcowy rezultat każdej gry - zwycięstwo czy porażka ${ }^{4}$. Obecnie debaty są szeroko rozpowszechnione $\mathrm{w}$ szkołach i na uniwersytetach na całym świecie. Większość krajów europejskich ma programy debat w każdej szkole.

Gra edukacyjna jest ważną metodą dydaktyczną, która intensyfikuje proces uczenia się i ściśle wiąże go z praktycznymi zajęciami. Dla nauczycieli-praktyków ${ }^{5}$ jest to metoda aktywnego uczenia się, polegająca na naśladowaniu, modelowaniu, odtwarzaniu rzeczywistej sytuacji pedagogicznej $\mathrm{w}$ formie gry. W nim każdy uczestnik odgrywa rolę, wykonuje czynności podobne do zachowania wychowawcy (nauczyciela), studenta (ucznia) lub innych podmiotów procesu edukacyjnego. Gra edukacyjna wykorzystywana jest jako metoda treningu praktycznego, służy

\footnotetext{
${ }^{4}$ Ортинський В. Л. Педагогіка вищої школи : навчальний посібник. Київ, 2009. C. 241-249.

5 Семенюк М. П., Яструб О. О. Навчально-педагогічні ігри у формуванні професіоналізму майбутнього вчителя. Вісник Черкаського національного університету імені Богдана Хмельницького. Серія «Педагогічні науки». 2012. № 24(237). C. 110-113.
} 
poznawaniu norm moralnych i etycznych, doskonaleniu umiejętności i zdolności do podejmowania właściwych decyzji w wyimaginowanych sytuacjach edukacyjnych ${ }^{6}$.

Specyfika pracy menedżerów, finansistów i innych profesjonalistów ekonomicznych wymaga odpowiednich decyzji zarządczych. Dla nich najlepszymi aktywnymi metodami nauczania będą metody: metoda projektowa, metoda modelowania sytuacji zawodowych, odgrywanie ról i gry biznesowe, organizacja „okrągłych stołów” i inne.

Metoda projektowa jest jedna $\mathrm{z}$ aktywnych metod nauczania. Powstała $\mathrm{w}$ latach dwudziestych XX wieku w Stanach Zjednoczonych. Projekty, nad którymi pracują studenci, mogą być kreatywne, społeczne, badawcze, eksploracyjne, więc metoda ta może być stosowana w szkoleniu różnych profesjonalistów. Metoda projektów opiera się na rozwijaniu umiejętności poznawczych, twórczych uczniów oraz krytycznego myślenia, umiejętności samodzielnego konstruowania swojej wiedzy, poruszania się w przestrzeni informacyjnej. Metoda projektowa to sposób na osiągnięcie celu dydaktycznego poprzez szczegółowe opracowanie problemu, co powinno zakończyć się bardzo realnym, namacalnym, praktycznym rezultatem, zaprojektowanym w taki czy inny sposób. Opiera się na idei interakcji i współpracy uczniów w procesie uczenia się i stwarza warunki do rozwoju różnych niezbędnych cech osobowości zarówno autonomicznej, jak i aktywnej społecznie, zdolnej do współdziałania $\mathrm{w}$ grupie badanej, podejmowania odpowiedzialności zarówno za osobiste, jak i kółko naukowe. Stwarza to warunki do socjalizacji jednostki, rozwija jej aktywność zawodową i biznesową. Są to cechy, których studenci potrzebują, aby stać się wykwalifikowanymi specjalistami. Role społeczne, które studenci przyjmują i odgrywają w trakcie pracy nad projektami (organizator, lider, wykonawca itp.) Uczą ich i przygotowują do wykonywania i rozwiązywania złożonych, problematycznych zadań zawodowych w sytuacjach rzeczywistej interakcji ${ }^{7}$.

Metoda modelowania konkretnych sytuacji (Case method) jest techniką uczenia się, która wykorzystuje opis rzeczywistych sytuacji ekonomicznych, społecznych i biznesowych, dlatego jest odpowiednia dla ekonomistów i menedżerów. Metoda modelowania konkretnych sytuacji jest silnym czynnikiem motywującym, gdyż pozwala na omówienie problemów związanych $\mathrm{z}$ przyszłą specjalnością. Istotą tej metody jest wykorzystanie konkretnych przypadków do wspólnej analizy, dyskusji czy podejmowania decyzji przez studentów $\mathrm{w}$ określonej sekcji dyscypliny, a także $\mathrm{z}$

6 Кочерга О. Використання ділової гри у процесі формування соціальної відповідальності майбутніх учителів початкових класів. Проблеми підготовки сучасного вчителя. 2012. № 6. Ч. 3. С. 49-56.

7 Бодько Л. Метод проектів як засіб реалізації особистісно орієнтованого навчання. Початкова школа. 2013. № 10. С. 1-4. 
powodzeniem łączenie działań dydaktycznych, analitycznych i edukacyjnych, co jest $\mathrm{z}$ pewnością skuteczna $\mathrm{i}$ wydajna $\mathrm{w}$ nowoczesnych zadaniach iystemy edukacji. Metoda ta zapewnia realizację następujących celów:

- zastosowanie wiedzy i umiejętności nabytych przez uczniów na zajęciach (umiejętności uczniów korelują z wiedzą teoretyczną z dyscyplin specjalnych i są zintegrowane w całościowy system wiedzy, umiejętności i zdolności);

- rozwój cech osobistych i zawodowych (umiejętność komunikowania się, słuchania rozmówcy, argumentowania i poprawnego wyrażania swojego punktu widzenia, odczuwania emocji podczas dyskusji, umiejętność organizowania i prowadzenia spotkań itp.);

- kształtowanie umiejętności aktywności zawodowej przyszłych specjalistów, zdolnych do adekwatnego podejmowania decyzji w różnych sytuacjach aktywności zawodowej ${ }^{8}$.

Forma zabawy polega na rozwiązaniu dyskusyjnego problemu i wyjściu z trudnej sytuacji, w jakiej znalazły się firmy lub instytucje - dilemma decision'. Uczniowie przedstawiają swoje konstruktywne metody i sposoby wyjścia z trudnej sytuacji, identyfikując się z pracownikami firmy i działając w jej imieniu. Po burzy mózgów i zbiorowym wyborze sposobu rozwiązania problemu, uczniowie są proszeni o nauczenie się, jak rozwiązać ten problem, który faktycznie miał miejsce. Tak więc ta metoda nauczania pomaga zwiększyć motywację do nauki, ponieważ świadomość uczniów, że nie tylko analizują problemy związane $\mathrm{z}$ przyszłymi specjalnościami, ale także omawiają rzeczywiste wydarzenia, pozwala im wierzyć w siebie i stanowi dodatkową zachętę do nauki. Ponadto moment gry w klasie pomaga rozładować napięcie, stworzyć pozytywny klimat emocjonalny, pozytywny charakter komunikacji i atmosferę interakcji. Uczniowie uczą się pracy $\mathrm{w}$ zespole i stwarzają sytuację współpracy, nabywają umiejętności prowadzenia dyskusji: logicznie układają własne wypowiedzi, potrafią słuchać rozmówcy, taktownie odpowiadać na jego przesłanie, argumentować swój punkt widzenia, poprawnie przedstawiać kontrargumenty, rysować wnioski; i, co ważne, wykazać się kreatywnym podejściem do rozwiązania problemu.

„Okrągły stól” to jedna z form organizacyjnych aktywności poznawczej studentów, która pozwala utrwalić wcześniej zdobytą wiedzę, uzupełnić brakujące informacje, ukształtować umiejętność rozwiązywania problemów, wzmacniać pozycje, poznawać kulturę dyskusji. Cechą charakterystyczną

${ }^{8}$ Гречановська О. В., Манглієва Т. Н. Сутність та використання кейс-методу в навчально-виховному процесі вищої школи. Матеріали конференції «XLVI Науковотехнічна конференція підрозділів Вінницького національного технічного університету (2017)». Вінниця, 2017.

9 Дяченко-Богун М. Активні методи навчання у вищому навчальному закладі. Витоки педагогічної майстерності. 2014. Вип. 14. С. 77. 
okrągłego stołu jest połączenie dyskusji tematycznej z konsultacją grupową. Wraz $\mathrm{z}$ aktywną wymianą wiedzy studenci rozwijają umiejętności zawodowe w zakresie wyrażania opinii, argumentowania racji, uzasadniania proponowanych rozwiązań oraz obrony swoich przekonań. Ważny warunek zorganizowania „okrągłego stołu”: konieczne jest, aby był rzeczywiście okrągły, czyli proces komunikacji, komunikacji odbywał się „twarzą w twarz”. Umiejscowienie uczestników naprzeciw siebie prowadzi do wzmożonej aktywności, zwiększenia liczby wypowiedzi, możliwości osobistego zaangażowania każdego ucznia w dyskusję, zwiększa motywację, obejmuje niewerbalne środki komunikacji takie jak mimika, gesty, przejawy emocjonalne $^{10}$.

Każda gra biznesowa ma cele edukacyjne i pedagogiczne. Treścią celów gry uczestnika jest pomyślne pełnienie roli, realizacja działań w grze, uzyskanie maksymalnej możliwej liczby punktów, unikanie kar, podejmowanie adekwatnych („rozsąanych”) decyzji itp. Treść celów pedagogicznych to rozwój profesjonalnego myślenia teoretycznego i praktycznego, umiejętności budowania relacji z innymi ludźmi, opanowania norm moralnych, rozwoju umiejętności ogólnych i zawodowych, kształtowania odpowiedzialnego podejścia do pracy i nie tylko.

Grze biznesowej towarzyszą różne motywy: produktywny, proceduralny, zbiorowy, indywidualny, społeczny, zawodowy, motywacja do osiągnięć, motywacja poznawcza. W zależności od dominujących motywów działania powstaje również odpowiedni typ osoby. Tak więc, jeśli w grze biznesowej przeważa motyw osiągnięć, to ukształtuje się adaptacyjny typ osobowości, poznawczo - produktywny (twórczy). Ze względu na osiągnięcie opanowania reguł gry i wszelkie zachowania w grze są uzależnione od osiągnięcia ostatecznego celu gry, kiedy gracze „blokują” wynik i „żyją” zgodnie z jego oczekiwaniami. Przy dominacji motywacji poznawczej uczestnicy ,żyją" grą, procesem jej rozłożenia w czasie, zainteresowaniem tym, czego się $\mathrm{w}$ grze uczą. Jednym $\mathrm{z}$ ważnych bodźców motywacyjnych jest umiejętność samodzielnego budowania aktywności w grze wyznaczanie celów, stawianie problemu, wybór działań i interpretacja roli.

Prawidłowa organizacja gry biznesowej obejmuje: jasne określenie jej celu i przebiegu pod względem łatwości i kreatywności; zapewnienie szybkiej informacji zwrotnej między liderem a jego uczestnikami; jak najbliżej rzeczywistych warunków i przepisów w czasie; rozwiązywanie bieżących problemów, $\mathrm{z}$ wykorzystaniem proponowanych algorytmów rozwiązań, możliwość wprowadzania zmian i uzupełnień do gry w zależności od zainteresowań uczestników; zapewnienie materiałów dydaktycznych (tabele,

${ }^{10}$ Гурч Л. М. Впровадження інноваційних педагогічних технологій: вимоги сучасності. Проблеми і перспективи розвитку фінансової системи Украӥни. 2003. Вип. 9. С. 151-153. 
teksty, diagramy); stymulowanie dyskusji na temat rozwiązania określonego problemu; umiejętność swobodnego wyrażania różnych opinii, odwoływania się do metod analizy i dowodzenia; unikanie autorytaryzmu: lider kieruje tylko uczestników do podejmowania możliwych decyzji, jego stosunek do uczniów jest przyjazny, główna metoda pracy - wyjaśnienie.

$\mathrm{W}$ ten sposób aktywne metody nauczania w tym gry biznesowe mogą być wykorzystywane do szkolenia różnych profesjonalistów, pozwalają utrwalać zdobytą wcześniej wiedzę, rozwijać umiejętności praktyczne, uzupełniać brakujące dane, umiejętność rozwiązywania problemów, pewność siebie, wiary we własne umiejętności. Pozwoli to osiągnąć jakościowo nowy poziom w nauce przedmiotów podstawowych i zawodowych, stwarzając warunki do kształcenia pokolenia młodych ludzi, dobrych fachowców i specjalistów, nowoczesnych, konkurencyjnych profesjonalistów.

\section{Problemy i wykorzystanie aktywnych metod nauczania w szkoleniu specjalistów ds. Bezpieczeństwa cywilnego}

Koncepcja szkolenia specjalistów w zakresie bezpieczeństwa cywilnego ukształtowała się jako system poglądów oparty na stanowiskach naukowych i teoretycznych, a także praktycznych podejściach do gruntownego szkolenia specjalistów $\mathrm{w}$ specjalnościach technicznych $\mathrm{z}$ zakresu bezpieczeństwa zawodowego, cywilnego i krajowego.

Specjalista ds. Bezpieczeństwa cywilnego może mieć specjalizacje, takie jak specyficzne dla branży bezpieczeństwo pracy, ochrona ludności, bezpieczeństwo wysokiego ryzyka, bezpieczeństwo i higiena pracy. Działalność specjalisty zakłada gotowość do aktywności zawodowej na wszystkich szczeblach praktyki, do rozwiązywania różnorodnych problemów z zakresu tworzenia bezpiecznych warunków pracy, utrzymania zdrowego i bezpiecznego życia oraz warunków ludzkich, zapewnienia bezpieczeństwa człowieka zarówno w życiu codziennym, jak i produkcyjnym oraz $w$ sytuacjach awaryjnych sytuacje, minimalizacja wpływu człowieka na środowisko, ochrona życia i zdrowia ludzi poprzez zastosowanie nowoczesnych środków technicznych, metod kontroli i prognozowania. Ustawodawstwo dotyczące bezpieczeństwa przemysłowego zmienia się i stale się rozwija. Eksperci ds. Bezpieczeństwa powinni uważnie monitorować takie zmiany.

W Państwach Unii Europejskiej, państwach członkowskich Europejskiego Porozumienia o Wolnym Handlu (EFTA) - stronach umowy o Europejskim Obszarze Gospodarczym oraz w Konfederacji Szwajcarskiej, przez kwalifikacje zawodowe rozumie się potwierdzone dyplomem, świadectwem lub innym dokumentem.

$\mathrm{W}$ różnych państwach specjaliści ds. Bezpieczeństwa mają różne kwalifikacje, zgodnie z normami krajowymi. Na przykład belgijskie prawo wymaga, aby duże firmy przemysłowe zatrudniały inżyniera ds. 
Bezpieczeństwa. W ostatnim czasie we współpracy $\mathrm{z}$ przemysłem zreorganizowano i rozbudowano program szkoleń dla specjalistów w tej dziedzinie. Ze względu na dużą różnorodność wiedzy i umiejętności, które należy opanować, program podzielono na dwie wersje. Jedną z opcji jest wyszkolenie specjalistów ds. Bezpieczeństwa $\mathrm{w}$ roli konsultantów ds. Prewencji. Inna opcja przygotowuje studentów do pracy w charakterze ekspertów technicznych $\mathrm{w}$ procesie bezpieczeństwa procesu. Oba programy rozpoczynają się od wspólnych ram składających się z następujących kursów: wprowadzenie do bezpieczeństwa, polityka zapobiegania i systemy zarządzania bezpieczeństwem, bezpieczeństwo produktów chemicznych i biologicznych oraz procesów chemicznych, środki bezpieczeństwa dla zakładów przemysłowych, metody analizy ryzyka jakości, bezpieczeństwo pożarowe i budowlane, wybuch ochrona. Po zakończeniu głównej części programu kontynuowane jest szkolenie $\mathrm{w}$ jednym $\mathrm{z}$ dwóch obszarów: bezpieczeństwa procesowego i zapobiegania zagrożeniom. Każdy $\mathrm{z}$ programów obejmuje następującą listę kursów: ilościowe metody analizy ryzyka, statystyki dla inżynierów bezpieczeństwa, zarządzanie procesami i bezpieczeństwo systemów cyfrowych, bezpieczeństwo procesowe, ergonomia i psychologia, medyczne konsekwencje zagrożenia dla innych odpowiednio ${ }^{11}$.

Nauki o bezpieczeństwie jako dyscyplina naukowa zostały oficjalnie zarejestrowane w Polsce w 2011 r. W dedykowanej dziedzinie nauk społecznych, wśród specjalizacji są: bezpieczeństwo narodowe, bezpieczeństwo wewnętrzne, inżynieria bezpieczeństwa ${ }^{12}$. Specjalizacja $\mathrm{z}$ bezpieczeństwa inżynieryjnego odpowiada specjalizacji z bezpieczeństwa cywilnego zawartej w normach edukacyjnych Ukrainy ${ }^{13}$.

Specjalność Bezpieczeństwo Cywilne (Bezpieczeństwo Pracy) jest jedną $\mathrm{z}$ najbardziej aktualnych i popularnych specjalności szkoleniowych i ukierunkowana jest przede wszystkim na szkolenie specjalistów, którzy są w stanie zapewnić skuteczną realizację polityki ochrony pracy, bezpieczeństwa pracy oraz współpracę $\mathrm{z}$ organami nadzoru państwowego zgodnie $\mathrm{z}$ przepisami i standardy międzynarodowe.

Specjalność pozwala na zdobycie praktycznej i specjalistycznej wiedzy i umiejętności z zakresu nauk technicznych i humanistycznych, związanych z zagrożeniami występującymi $\mathrm{w}$ procesie pracy, metodami eliminacji

11 Гарматюк Д., Сербулова К. Магістр наук в галузі техніки безпеки в KU Leuven, Бельгія. Безпека життя $i$ діяльності людини - освіта, наука, практика. Львів, 2018. С. 21-22.

12 Korzeniowski L., Wałek T. Edukacja dla bezpieczeństwa na polskich uniwersytetach. Securitologia, 2017, No 2, P. 1-17.

13 Дацько О. С., Романів А. С., Параняк Н. М. Реформа освіти і перспективи викладання курсу «безпека життєдіяльності» у вузах. Комунальне господарство міст. Серія «Безпека життя і діяльності людини - освіта, наука, практика». 2015. Вип. 120(1). С. 111-113. 
zagrożeń, oceną ryzyka zawodowego itp. Absolwenci potrafią zinterpretować rolę i miejsce osoby w rozwiązywaniu problemów BHP ze wszystkimi tego konsekwencjami. Celem specjalistów ds. Bezpieczeństwa cywilnego i ochrony pracy jest realizacja zadania obowiązkowego ubezpieczenia społecznego $\mathrm{z}$ tytułu wypadków przy pracy i chorób zawodowych, w szczególności zapewnienie pracodawcy działań prewencyjnych $i$ innych mających na celu eliminację szkodliwych i niebezpiecznych czynników produkcji, zapobieganie wypadkom w sprawie produkcji, chorób zawodowych i innych przypadków zagrożenia zdrowia personelu spowodowanego warunkami pracy oraz udzielania praktycznej pomocy pracodawcy $\mathrm{w}$ ciągłym doskonaleniu form i metod pracy profilaktycznej w zakresie ochrony pracy.

Międzynarodowe statystyki pokazują, że wypadki przy pracy można porównać do epidemii. Śmiertelność z tytułu wypadków przy pracy zajmuje trzecie miejsce na Ukrainie po chorobach układu krążenia i nowotworach (w krajach rozwiniętych gospodarczo poziom wypadków przy pracy jest czterokrotnie niższy). Na Ukrainie co pięć godzin umiera jedna osoba, co osiem minut jest kontuzjowana. Główną przyczyną śmierci pracowników są urazy przy pracy. Liczba zgonów przy pracy na 100000 pracowników na Ukrainie jest dwukrotnie wyższa niż w Unii Europejskiej. Tak duża liczba wypadków wiąże się przede wszystkim z niezadowalającym przeszkoleniem pracowników i pracodawców $\mathrm{w}$ zakresie bezpieczeństwa pracy oraz niedociągnięciami $\mathrm{w}$ pracy organizacyjnej wsparcia informacyjnego dla bezpieczeństwa pracy.

Zapewnienie bezpieczeństwa pracy jest zadaniem bardzo trudnym, wymagającym zrozumienia zagadnień o różnym charakterze: aspektów zachowania człowieka, dlatego ekspert ds. Bezpieczeństwa musi znać podstawowe zasady psychologii oraz techniczne aspekty wykonywania pracy. Rozwój bezpiecznych procesów produkcyjnych wymaga znajomości metod identyfikacji i oceny zagrożeń. Ważne jest, aby uczyć się na podstawie incydentów i wypadków z przeszłości, dlatego istnieje potrzeba posiadania specjalnych umiejętności statystycznych, aby zidentyfikować przyczyny i opracować działania naprawcze. Dlatego też, aby ćwiczyć takie umiejętności, właściwe będzie zastosowanie metody modelowania konkretnych sytuacji (Case method).

Przygotowanie i przeprowadzenie gry biznesowej odbywa się w kilku etapach:

1) Wybór tematu zawierającego zadanie lub sytuację wymagającą opracowania i podjęcia określonych decyzji.

2) Ustalenie celu gry, składu i funkcji jej uczestników.

3) Opracowanie modelu gry, który powinien w pełni odzwierciedlać proces produkcyjny lub sytuację praktyczną. Należy pamiętać, że gra - to 
rzeczywistość uproszczona, polegająca na symulacji wpływu na proces produkcyjny środowiska zewnętrznego i relacji z nim.

4) Opracowanie kryteriów oceny pracy studentów. Głównym motywem gier edukacyjno-pedagogicznych i głównym kryterium oceny powinno być skuteczne zastosowanie wiedzy teoretycznej uczniów w praktyce, a także efektywna interakcja $\mathrm{z}$ innymi uczestnikami gry.

5) Zapoznanie studentów z celem gry i sytuacją produkcyjną, podziałem ról i zwróceniem uwagi na kryteria oceny. Należy to zrobić tydzień przed meczem. Jednocześnie uczniowie muszą mieć listę zalecanych lektur. Przy rozdzielaniu ról i „stanowisk” między uczestników należy wziąć pod uwagę poziom ich wiedzy, umiejętności i indywidualnych cech. Ważne jest, aby role nie były trwałe we wszystkich grach.

6) Przebieg gry i analiza jej wyników.

W grach każdy etap jest znormalizowany w czasie. Końcowy wynik rozgrywki zależy od jakości podejmowanych decyzji i zgodności z trybem czasowym rozgrywki.

Aby zapewnić wymaganą jakość gry, organizator musi kierować się określonymi dokumentami:

1) Prospekt gry biznesowej, który określa wykonalność jej przeprowadzenia, uwzględniając cel, cele i warunki gry; określenie danych początkowych, obiektów gry; przegląd możliwych metod badania problemów itp.

2) Scenariusz gry biznesowej, który zawiera zestaw ról w grze i ich opis, podział obowiązków, zasady gry. Zasady gry zawierają ograniczenia dotyczące technologii, regulacji elementów gry lub ich procedur, roli i funkcji ,nauczyciela - lidera”, systemu ocen; zasady nie powinny przekraczać 5-10. Muszą zapewniać odwzorowanie rzeczywistego i biznesowego kontekstu gry, a także być powiązane z systemem zachęt.

3) Opis środowiska gry. Uwzględnia metody i formy (ustne, pisemne, z wykorzystaniem obiektów gry) powiązań informacyjnych między uczestnikami.

4) Instrukcje dla uczestników. Ten dokument zawiera zadania w grze $i$ sposoby ich rozwiązywania dla każdej roli, a także cechy relacji i obowiązków uczestników.

5) Prowadzenie i dostosowywanie uczestników gry. Zapewnia wszystkie podstawowe mierniki jakości przygotowania warunków gry, jej uczestników, niezbędną dokumentację.

Podczas konstruowania treści gry biznesowej ważne jest, aby zachęcić uczniów do aktywności poznawczej przez cały czas trwania gry. Można to osiągnąć poprzez tworzenie sytuacji problemowych, trudności intelektualnych, które wymagają aktywnego współdziałania uczniów z przedmiotami wiedzy, pokonywania sprzeczności między wiedzą znaną a potrzebą „odkrywania” lub 
znajdowania nowej wiedzy, umiejętności, które z kolei będą sprzyjać rozwojowi. łączenie nowych zadań poznawczych dla uczniów.

Druga grupa szkoleń to zadania sytuacyjne symulujące udzielenie pierwszej pomocy poszkodowanym na miejscu zdarzenia ${ }^{14}$. W tym miejscu celowe jest wyznaczenie zadań zarówno medycznych zadań sytuacyjnych, jak i aktywnego modelowania przez studentów sytuacji klinicznych w stanach nagłych. Przyczynia się to do aktywnego zdobywania wiedzy, zrównoważonego uczenia się materiałów edukacyjnych; kształtuje umiejętności praktyczne, rozwija zainteresowanie procesem edukacyjnym; zapewnia aktywną i efektywną interakcję edukacyjno-pedagogiczną między uczniem a nauczycielem, przenosi akcent $\mathrm{z}$ działań nauczyciela na aktywność ucznia, gwarantuje maksymalną niezależność w jego pracy. Rozwija zrozumienie patologii ofiary w rzeczywistej sytuacji, umiejętność analizy jego stanu i doboru optymalnych działań ratownictwa medycznego; w typowych przypadkach przeprowadzana jest automatyczna reakcja. W tym samym czasie tworzony jest operacyjno-logistyczny algorytm wiedzy i podejmowana jest właściwa decyzja nawet $\mathrm{w}$ warunkach stresu, braku czasu, w nietypowych sytuacjach. Wiedza i umiejętności są zobiektywizowane na podstawie ciągłego sprzężenia zwrotnego; nauczyciel ma możliwość oceny stopnia przyswojenia materiału edukacyjnego przez każdego ucznia.

Sytuacja awaryjna charakteryzuje się obecnością różnych niebezpiecznych czynników i zagrożeń, które niekorzystnie wpływają na zdrowie fizyczne człowieka. Jednocześnie na osobę wpływają również psychiczne czynniki traumatyczne. Dlatego niezbędny jest trening moralny i psychologiczny, który $w$ nagłych wypadkach zapewnia przemyślane, racjonalne działania, a tym samym stabilność psychiczną.

Ludzie różnie reagują na niebezpieczeństwo. Sytuacje ekstremalne powodują złożone stany psychiczne: strach, apatię, otępienie, nerwowe drżenie, lęk, agresję, stres i panikę. Procesy myślenia, reakcje emocjonalne i motoryczne są zaburzone. W przypadku sytuacji awaryjnej niezwykle cenne będą umiejętności podejmowania decyzji w celu przezwyciężenia sytuacji awaryjnej, a także trening psychologiczny $\mathrm{w}$ zakresie redukcji stresu $\mathrm{w}$ ekstremalnych warunkach. W sytuacji awaryjnej dana osoba znajduje się $\mathrm{w}$ stanie silnego stresu psychicznego, a jego zachowanie w tych chwilach często zależy od tego, czy skuteczne będzie przeciwdziałanie negatywnym czynnikom, które to zdarzenie niesie. Nacisk na moralne i psychologiczne aspekty bezpieczeństwa i rozwoju umiejętności w grze sytuacyjnej nauczy uczniów umiejętności opierania się strachowi i zdezorganizowanym działaniom w sytuacjach ekstremalnych, chęci przezwyciężenia własnej

\footnotetext{
14 Телегіна Г. В. Деякі аспекти удосконалення першої медичної допомоги при надзвичайних ситуаціях. Матеріали 15-ї Всеукраӥнської науково-практичної конференції рятувальників. Київ, 2013. С. 281-283.
} 
niepewności i niezdecydowania. W większości przypadków skutkiem paniki wśród ofiar jest ignorancja, niski poziom przygotowania do działania $\mathrm{w}$ nagłych wypadkach, brak zaostrzenia psychicznego, brak prawdziwych informacji. Uwzględnienie bezpieczeństwa psychicznego i wytrzymałości w sytuacjach ekstremalnych da uczniom nie tylko ogólne wyobrażenie o zagrożeniach, ale także nauczy ich wykorzystywania wiedzy zdobytej $\mathrm{w}$ przyszłym zawodzie, właściwej oceny sytuacji niebezpiecznych i podejmowania optymalnych decyzji bez utraty równowagi psychicznej ${ }^{15}$.

$\mathrm{U}$ podstaw treningu psychologicznego studenta leżą zasady wprowadzania do procesu edukacyjnego elementów napięć, niespodzianek, które są nieodłącznie związane z rzeczywistą sytuacją w obszarze katastrofy, wypadku, uszkodzenia, praktycznego szkolenia $\mathrm{z}$ metod ich ochrony. Dlatego jednym $\mathrm{z}$ obszarów treningu moralno-psychologicznego jest doskonalenie umiejętności samopomocy i wzajemnej pomocy ofiarom oparzeń, urazów, infekcji, promieniowania, posługiwania się apteczkami, środkami ochrony indywidualnej, znajomość przyrządów dozymetrycznych i urządzeń rozpoznania chemicznego, praktyka pracy z nimi.

Studenci muszą mieć jasne wyobrażenie o podstawowych mechanizmach obronnych organizmu ludzkiego, wiedzieć o bezpieczeństwie i przetrwaniu człowieka w przypadku określonych sytuacji kryzysowych (trzęsienia ziemi, powodzie, huragany, pożary itp.), przejść szkolenie psychologiczne i psychotechnikę w sytuacjach niebezpiecznych stosować techniki zarządzania stresem w sytuacjach ekstremalnych.

Osobowość kształtuje się pod wpływem środowiska społecznego i wychowania. Dlatego wskaźnikiem bezpieczeństwa człowieka lub jego skłonności do niebezpieczeństwa jest nie tyle wrodzona cecha, ile wynik jego rozwoju. Niedostateczne ukształtowanie indywidualnych cech osobowości (siła woli, odwaga, determinacja) przejawia się oczywiście w sytuacjach ekstremalnych. Brak równowagi emocjonalnej, niezdolność do szybkiego rozdzielenia uwagi i wyodrębnienia głównego obiektu niebezpieczeństwa wśród wielu innych, niewystarczająca wytrzymałość i nadmierne (zbyt duże lub nieznaczne) podejmowanie ryzyka znacznie zwiększają podatność osoby na niebezpieczeństwo. Dlatego, aby udzielić pierwszej pomocy sobie i swoim bliskim w skrajnej sytuacji, musisz nie tylko nauczyć się pewnych sposobów zarządzania swoją świadomością, ale także umiejętności rozpoznawania reakcji ludzi na sytuacje awaryjne i prawidłowej komunikacji z nimi.

Twórcza praca na zajęciach aktywuje więc aktywność umysłową, formuje logiczne, w tym asocjacyjne myślenie. Student dostrzega swoje

15 Дацько О. С., Романів А. С. Питання психологічного захисту у надзвичайних ситуаціях при вивченні курсів БЖД та ЦЗ. Особистість в екстремальних умовах : матеріали V науково-практичної конференції. Львів, 2012. С. 67-69. 
błędy, uczy się odróżniać prawdopodobne od tendencyjnego i znajdować rozsądne rozwiązanie; zdobywa praktyczne doświadczenie. Absolwenci będą przychodzić do pracy i ostatecznie kierować organizacjami lub ich jednostkami, stając się jednocześnie szefami i organizatorami obrony cywilnej w określonym obszarze. W naszym środowisku stworzonym przez człowieka coraz więcej odchyleń od normalnego przebiegu procesu produkcyjnego, stanu środowiska naturalnego, dlatego coraz częściej w naszym życiu możemy stawić czoła sytuacjom ekstremalnym.

\section{WNIOSKI}

Reforma edukacji na Ukrainie przyczyniła się do konieczności zwiększenia efektywności procesu edukacyjnego. Można to osiągnąć poprzez zmniejszenie nieprodukcyjnych kosztów czasu zajęć, poszerzenie możliwości samokształcenia, poprawę jakości nauczania.

Doskonalenie metod $\mathrm{i}$ form kształcenia jest jednym $\mathrm{z}$ obszarów modernizacji systemu edukacyjnego Ukrainy. W nauczaniu dyscyplin $\mathrm{z}$ zakresu bezpieczeństwa cywilnego konieczne jest stosowanie takich metod nauczania, które będą sprzyjały samorealizacji uczniów. Dlatego też samorealizacja uczniów jest możliwa w takich warunkach, jak organizacja pracy grupowej i zapewnienie interakcji między sobą, $\mathrm{z}$ procesem edukacyjnym i informacją edukacyjną.

Spośród różnych form organizacji zajęć, uczniowie najbardziej interesują się grami, sytuacjami związanymi z grami, ponieważ przybliżają proces uczenia się do realnego życia, przyczyniają się do kształtowania umiejętności praktycznych, zapewniają praktyczną orientację w nauce.

Gra przyczynia się do kształtowania pozytywnej motywacji do nauki, czyli chęci zaangażowania, potrzeby, zainteresowania. Gra pozwala dostrzec sukcesy, a nie dostrzec porażek. I odwrotnie, sukces prowadzi do zwycięstwa, zwycięstwo do motywacji, motywacja - do chęci zwycięstwa i nowych sukcesów.

Uczenie się, jako proces dwukierunkowy, jest interakcją uczniów i nauczycieli, więc może być skuteczne tylko wtedy, gdy wysiłki obu stron. Celem uczenia się w nowoczesnych warunkach jest nie tyle zdobywanie wiedzy, umiejętności i zdolności z wybranej specjalności, co przygotowanie studentów do samokształcenia, rozwijanie ich zainteresowań uczeniem się oraz kształtowanie potrzeb poznawczych. Aktywne metody nauczania pozwalają na realizację postawionych zadań oraz sprzyjają rozwojowi osobistemu i zawodowemu.

Dzięki aktywnym metodom nauczania lepiej rozwijają się indywidualne możliwości uczniów, ponieważ nie odczuwają oni psychologicznej presji odpowiedzialności, która jest nieodłącznym elementem normalnych zajęć edukacyjnych. W trakcie gry akcja uczy się poprzez samą akcję. Asymilacja wiedzy odbywa się w kontekście określonej czynności, która stwarza 
sytuację zapotrzebowania na wiedzę. Gra pozwala pozbyć się schematów i stereotypów, może zmienić stosunek uczniów do dowolnego zjawiska, faktu, problemu. Stymuluje aktywność intelektualną uczniów, uczy przewidywania, badania i sprawdzania poprawności decyzji i hipotez, kultywuje kulturę komunikacji, rozwija umiejętność pracy w zespole i zespole. Wszystko to determinuje funkcje gry edukacyjnej jako środka psychologicznego, społeczno-psychologicznego i pedagogicznego oddziaływania na jednostkę.

\section{ABSTRAKT}

Badania dotyczą problemu aktywnych metod nauczania w kształceniu specjalistów na uniwersytetach Ukrainy i niektórych krajów europejskich. Podano przegląd metod nauczania gier interaktywnych i ich zastosowania w szkoleniu różnych specjalistów. Uwzględniono problemy, które mogą pojawić się $\mathrm{W}$ działalności specjalistów ds. Bezpieczeństwa. Podano przykłady wykorzystania metod aktywnego uczenia się, gier biznesowych i zadań sytuacyjnych. Metoda modelowania konkretnych sytuacji okazała się najlepszym sposobem rozwiązywania problemów, które mogą pojawić się w miejscu pracy $\mathrm{w}$ razie wypadku spowodowanego przez ludzi, sprzęt lub $\mathrm{w}$ przypadku klęski żywiołowej. Trening i zadania sytuacyjne pozwalają na ćwiczenie umiejętności udzielania pierwszej pomocy medycznej i psychologicznej. Wiedza ta pozwoli studentom wykorzystać je w przyszłym zawodzie, poprawnie ocenić niebezpieczne sytuacje i podejmować optymalne decyzje chroniące przed zagrożeniami.

\section{BIBLIOGRAFIA}

1. Korzeniowski L., Wałek T. Edukacja dla bezpieczeństwa na polskich uniwersytetach. Securitologia. 2017. № 2. P. 1-17.

2. Бодько Л. Метод проектів як засіб реалізації особистісно орієнтованого навчання. Початкова школа. 2013. № 10. С. 1-4.

3. Гарматюк Д., Сербулова К. Магістр наук в галузі техніки безпеки в KU Leuven, Бельгія. Безпека життя $і$ діяльності людини освіта, наука, практика. Львів, 2018. С. 21-22.

4. Гречановська О. В., Манглієва Т. Н. Сутність та використання кейс-методу в навчально-виховному процесі вищої школи. Матеріали конференції «XLVI Науково-технічна конферениія підрозділів Вінницького національного технічного університету (2017)». Вінниця, 2017. URL: https://conferences.vntu.edu.ua/index.php/all-hum/all-hum2017/paper/ download/2064/1594.

5. Гурч Л. М. Впровадження інноваційних педагогічних технологій: вимоги сучасності. Проблеми $i$ перспективи розвитку фінансової системи Украӥни. 2003. Вип. 9. С. 151-153. 
6. Дацько О. С., Романів А. С., Параняк Н. М. Реформа освіти і перспективи викладання курсу «безпека життєдіяльності» у вузах. Комунальне господарство міст. Серія "Безпека життя $і$ діяльності людини - освіта, наука, практика». 2015. Вип. 120(1). С. 111-113.

7. Дацько О. С., Романів А. С. Питання психологічного захисту у надзвичайних ситуаціях при вивченні курсів БЖД та ЦЗ. Особистість в екстремальних умовах : матеріали V науково-практичної конференції. Львів, 2012. С. 67-69.

8. Дяченко-Богун М. Активні методи навчання у вищому навчальному закладі. Витоки педагогічної майстерності. 2014. Вип. 14. С. 74-79.

9. Кочерга О. Використання ділової гри у процесі формування соціальної відповідальності майбутніх учителів початкових класів. Проблеми підготовки сучасного вчителя. 2012. № 6. Ч. 3. С. 49-56.

10. Ортинський В. Л. Педагогіка вищої школи : навчальний посібник. Київ, 2009. С. 241-249.

11. Семенюк М. П., Яструб О. О. Навчально-педагогічні ігри у формуванні професіоналізму майбутнього вчителя. Вісник Черкаського національного університету імені Богдана Хмельницького. Серія «Педагогічні науки». 2012. № 24(237). С. 110-113.

12. Телегіна Г.В. Деякі аспекти удосконалення першої медичної допомоги при надзвичайних ситуаціях. Матеріали 15-ї Всеукраїнської науково-практичної конференції рятувальників. Київ, 2013. С. 281-283.

\section{Information about the authors:}

Datsko O. S.,

Candidate of Sciences in Technology, Associate Professor, Associate Professor at the Department of Civil Safety

Lviv Polytechnic National University 12, S. Bandera str., Lviv, 79013, Ukraine

Paraniak N. M.,

Candidate of Sciences in Technology, Associate Professor at the Department of Civil Safety

Lviv Polytechnic National University 12, S. Bandera str., Lviv, 79013, Ukraine 